\section{Embattled US ecologists}

SIR - The embattled ecologists of the United States are faced with a multitude of obstacles and choices, including budget cuts and demonization from the Right. However, one crossroads that they thankfully are not at is the "level-headed compromise" that is characteristic of political animals, rather than the ecologically concerned (Nature 376, 461; 1995).

The implication throughout Henry Gee's leading article is that US ecologists are to blame for their public image 'problems' which have resulted in, among other events, the failure of the United States to ratify the Biodiversity Treaty from the Rio de Janeiro conference. This is supposedly because they have "failed to distance themselves from unfocused environmental activism".

At some point scientists are faced with politico-cultural realities associated with their subject of study which is often also their passion. In his waning years, Einstein advocated elimination of nuclear weapons manufacture, the development of which was largely facilitated by his own discoveries. Ecologists today are faced with an impending disaster not of their own making that may nevertheless destroy the object of their own focus. Environmental legislation in the United States is fraught with the very compromises Gee advocates. But the inevitable result of continuous compromise is an end product that has no discernible relationship to the original article.

As Gee points out, US ecologists should indeed look to the United Kingdom for lessons on ecological projection and protection. This cultural ancestor of the United States has managed to compromise its ecology to the point where it can boast no wilderness areas, ocean-to-ocean pasturage and urban development, and a regularly declining economic situation. Without avid advocacy, US ecologists of future centuries may also find themselves studying hedgerow 'ecosystems' in the formerly wild Rocky Mountains.

Contrary to Gee's assertion, US ecologists cannot compromise on end-game legislation such as the Endangered Species Act, now under review by Congress under the aegis of their industrial suppliers. The act comprises a stop-gap measure to reduce anthropogenic extinction of non-human species and has proved functional, an illustrious example being the national bird of the United States, the bald eagle. The role of publicly funded ecologists in the United States is to inform the public and/or the voters of the goingson in the natural world. If human societies and agencies cause damage to our world, then ecologists should welcome even the odd "hirsute" environmental activist as a bedfellow in their mission to expose this damage. As scientists we can be both objective observers and passionate advocates of the natural processes we love. Indeed, we have been doing so for centuries already.

\section{Fraser Shilling}

(Chair, Committee on Conservation

American Society of Zoologists)

Division of Biological Sciences,

University of California, Davis,

Davis, California 95616-8535, USA

\section{Katyn massacre}

SIR - I read with interest your leading article on rewriting history (Nature 376, $539,1995)$ and I agree with your view that teaching contemporary history is important. In this spirit, I should like to elaborate on your reference to the massacre at Katyn.

In 1939, 17 days after Germany invaded Poland from the west, Soviet forces invaded the eastern half of Poland without declaring war. Among other people detained and transported inside the Soviet Union were more than 20,000 Polish officers. They were kept in several different prison camps, the three best-known being Katyn, Starobielsk and Ostaszkowo. Virtually all were exterminated in the spring of 1940, probably by the order of Stalin himself. Executions were carried out in various localities close to the camps. The mass grave near Katyn was the first one to be discovered by the Germans after they in turn invaded this part of the Soviet Union in 1941. It contained more than 4,000 bodies.

Nobody knows all of Stalin's motives and I agree that vindictiveness played a large role. However, it seems that executions of Polish officers were something more than an act of vengeance. Most of those officers were not professional soldiers, but reservists mobilized at the beginning of the German invasion of Poland.

There were many thousands of other soldiers and civilians in the Soviet prison and labour camps during the Second World War. Many of them perished, but as far as I know they were not subjected to mass execution.

Extermination of the officers was probably a part of the policy to annihilate the Polish intelligentsia, which was carried out by both the German and Soviet occupying forces during the Second World War, and continued for some time after the war by the communist government installed by the Soviets in Poland.

\section{Grzegorz Sẹdek}

46 Longview Trail.

Denville, New Jersey 07834, USA

\section{Visual processing}

SIR - The results of Morrone et al. ${ }^{1}$ imply the existence of specialized detectors that integrate signals of different directions from different locations, leading to the inference that composition in (visual) art is a consequence of the existence of specific circuits.

Composition $^{2}$ means the body of rules defining the disposition of the parts of a work of art to draw the observer's attention to the essential. In a sense, the viewer perceives (mostly unconsciously) a 'super-pattern', a 'compositional gestalt' in Köhler's sense $^{3}$. Among the dominant compositional elements are the two diagonals, the circle, some straight horizontals and verticals as well as their combinations. What is remarkable about the rules of composition is their generality. They are consistently respected from 30,000 BP (Chauvet Cave ${ }^{4}$ ) to the twentieth-century abstractions and over the five continents, so that they seem to be universal and not merely artistic conventions. So why not conjecture that composition in visual art is determined by innate radial, circular and translational visual processing?

\section{Michel Benarie}

European Cultural Heritage Newsletter, 20 Bd Jean Pain,

38000 Grenoble, France

1..Morrone, M. C. et al. Nature 376, 507-509(1995)

2. Poore, H. R. Composition in Art (Avenel, New York, 1967).

3. Kohler, W. Gestalt Psychology (New York and London, 1929).

4. Chauvet, J.M. et al. La grotte Chauvet (Seuil, Paris, 1995)

\section{Unsung hero}

SIR - Marconi's contribution to wireless transmission is often mentioned in scientific journals (see, for example, H. C. Alexander, Nature 373, 184; 1995). Sir Jagadish Chandra Bose (no relation to Satyendranath Bose of Bose-Einstein statistics fame) made his contribution to wireless transmission before Marconi.

Some years ago, in Physics Today (39, 36-44; 1986), Dr W. A. Blanpied wrote:

In 1895 Bose gave a public lecture at Town Hall, Calcutta, in which he demonstrated for the first time wireless transmission of electromagnetic signals through solid walls; it quickly made him famous throughout Bengal. As a result of the growing fame, the government of Bengal sent him on a nine-month lecture tour of Europe, where in December 1896 he repeated his demonstrations of wireless transmission at the Royal Institution before an audience that included Lord Kelvin. That event anticipated by a year Guglielmo Marconi's more celebrated (and commercially exploited) wireless-transmission demonstrations in the same city.

\section{Amal K. Das}

Department of Physics,

Dalhousie University,

Halifax, Nova Scotia,

Canada B3H 3J5 